\title{
Regionális nemzetiségi politikai pártok Olaszországban. Tanulságok és tapasztalatok az európai őshonos kisebbségek számára
} Regional Ethnic Political Parties in Italy. Lessons and Experiences for Indigenous Minorities in Europe

Berényi Márk

https://doi.org/10.47707/Kulugyi_Szemle.2020.4.02

Összefoglaló: Európában - különös tekintettel Skóciára, Katalóniára, Baszkföldre vagy éppen Erdélyre és a Székelyföldre - egyre többször esik szó autonómiáról, autonómiatörekvésekről, regionális nemzetiségi politikáról. A jelen tanulmány át kívánja tekinteni azt a sajátos és történelmi viszonylatból nézve bizonyosan sikeres nemzetiségi politikát, amelyet Olaszország és az ott múködő nemzetiségi pártok a 20. század második felében közösen megvalósítottak. A cikk áttekinti annak a három - németajkú, frankofón és szlovén - nemzeti kisebbségnek a helyzetét, amelyek politikai képviselettel is rendelkeznek az olasz intézményrendszeren belül, külön kitérve Dél-Tirol sajátos politikai berendezkedésére és autonómiájára, amely látszólag a terület lakosai közötti békés együttélés záloga. A tanulmány - általános deskriptív és historikus céljain túl - a mai Olaszország területén élő őshonos kisebbségek autonómiatörekvéseinek a bemutatásán keresztül támpontokat és mintákat szeretne adni napjaink hasonló sorshelyzetben élő európai nemzeti kisebbségeinek ahhoz, hogy békés és megnyugtató megoldást találjanak az életük rendezéséhez, céljaik eléréséhez.

Kulcsszavak: autonómia, Olaszország, nemzetiségi pártok, nemzetiségi kisebbségek, Dél-Tirol

\begin{abstract}
Recently in Europe, due to the Scottish, Catalan, Basque and Transylvanian situations, we are getting used to paying more attention to the topic of the autonomy aspirations and the regional minority policies. The purpose of this article is to deeply understand and analyse the evolution of the minority policy of Italy that has been created by the country's numerous nationality parties during the second half of the 20th century, and which could be judged, from a historical point of view, as successful and prosperous achievement. In this study we are going to review the situation of three national minorities in Italy that are represented in the legislative institutions of Italy - the German-speaking, the Francophone and the Slovenian - with a specific focus on South Tirol, on its political structure and its autonomy which are, without a doubt, the foundation of a pacific cohabitation in the region. Apart from its universal descriptive and historical narrative, this study is aimed at equipping all European ethnic minorities (in similar social-political situation in their regions) with successful models and examples of the aforementioned introduction and ratification of autonomy aspirations of indigenous minority communities of today's Italy in order to find pacific and comforting solutions to settle their own lives and achieve their own goals.
\end{abstract}

Keywords: autonomy, Italy, nationality parties, national minorities, South Tirol 


\section{Bevezető}

Olaszország esetében már-már közhelynek számít az ország nyelvi-dialektális tagoltsága, illetve az olasz politika regionális jellege. Azonban az is általánosan megfigyelhető, hogy nem a kellő pontossággal használjuk a regionális jelzőt. A belső tagoltság történelmi időkre visszavezethető jelenség. Gondoljunk csupán a mai Olaszország területén egykor létezett középkori városállamokra, majd a későbbi megannyi önálló grófságra, hercegségre, nagyhercegségre, királyságra vagy éppen magára a Pápai Államra. E valamikori politikai megosztottság okán Olaszország kulturális földrajza napjainkban is meglehetősen heterogén képet mutat, s ez természetesen visszatükröződik a helyi érdekvédelmi pártok, szervezetek, szövetségek létében és választási sikereiben is.

Az előbb felsoroltakon túl szót kell ejtenünk azokról a földrajzi régiókról is, amelyek a történelem viharai során kerültek az ország területéhez, és amelyek lakosainak a többsége nem az olasz nyelvet - vagy annak egyes tájnyelvi változatát - tekintik az anyanyelvüknek, illetve kulturálisan is csak laza szálakkal kötődnek az olasz csizmához.

Mindezek következtében - legalábbis Olaszország esetében - a nyelvi-kulturális regionalizmus két konvencionális altípusát vagyunk kénytelenek megkülönböztetni: az olasz nyelven belüli és az azon kívüli regionalizmust. Az olasz nyelven belüli - nevezzük "belső" regionalizmusnak - altípusba azokat a pártokat, mozgalmakat vagy politikai irányzatokat sorolhatjuk, amelyek egy adott, többségében olaszajkú terület (ilyen Szicília, Szardínia, de akár a tág értelemben vett Észak-Olaszország is) gazdasági érdekeit, helyi sajátosságait, népszokásait, természeti és épített környezetét szeretnék kedvezőbb helyzetbe hozni az olasz törvényhozásban és általában az olasz intézményrendszer berkein belül. Erre olyan pártokat lehet példaként felhozni, mint a Szárd Akciópárt (Partito Sardo d'Azione, PSd'Az) Szardíniában, az egykori Hálózat (La Rete) mozgalom Szicíliában, illetve a korábbi Északi Liga (Lega Nord, amely napjainkban már csak a Liga nevet viseli') Észak-Olaszországban. Amint látni fogjuk, nem lehet elkerülni, hogy a Szárd Akciópárttal, ha csak említés szintjén is, ne foglalkozzunk, azonban alapvetően az ottani belső regionalizmus ezúttal nem képezi a vizsgálódásunk tárgyát.

Amennyiben a regionalizmusnak az olasz nyelven kívüli altípusát vizsgáljuk - nevezzük ezt "külső" regionalizmusnak -, akkor azt tapasztalhatjuk, hogy léteznek olyan (egy adott területen akár a többségi társadalmat is képező) nyelvi kisebbségek, amelyek rendelkeznek az adott etnikum jogait, érdekeit, autonómiáját képviselő, saját nemzetiségi pártokkal. Ferdinand Müller-Rommel (1998) ez utóbbiakat az etnoregionális jelzővel illeti, és a meghatározása szerint e pártok a politikájukat egy földrajzilag körülhatárolható,

1 Az Északi Liga 1989 és 1991 között fokozatosan jött létre, hat északolasz regionális érdekvédelmi párt és szervezet fúziójával. A kezdetben kifejezetten a helyi érdekeket képviselő párt a hivatalos megnevezéséből 2017-ben eltávolította az északi jelzőt, amellyel szimbolikusan is jelezte, hogy immáron országos szinten kíván politizálni. 


\section{Külügyi Szemle}

többnyire periférián élő kisebbség törekvéseinek a képviseletére építik. A jelen vizsgálódásunk tárgyát ezek fogják képezni.

Amennyiben Giovanni Sartori (1976, 78-81. o.) szempontrendszerét vesszük figyelembe arra vonatkozóan, hogy voltaképpen mi tesz sikeressé egy etnoregionális pártot, akkor mindenképpen meg kell említenünk az adott pártnak az ország pártrendszerére gyakorolt hatását, a választói bázis erejét, a párt koalíciós képességét vagy éppen zsarolási potenciálját. A 20. század során Európát meggyötrő viszontagságok, amelyekben Olaszország hol sértettként, hol pedig agresszorként vett részt, azzal a következménynyel jártak, hogy az ország területén napjainkra - Sartori említett szempontrendszere szerint - három csoport bír jelentős, de nem azonos politikai súllyal. Ezek a németajkú (főként az Oberdeutsche Dialekte, azon belül is a Südbairische Dialekte), a francia (annak is elsősorban a franko-provanszál nyelvjárása), továbbá a szlovén kisebbségek. Bár semmiképpen sem szabad megfeledkeznünk a Dél-Itáliában fellelhető görög (főként Puglia, Calabria és Szicília tartományban) és albán (elsősorban Basilicata, Calabria és Szicília régióban élő) kisebbségekről, azok gazdag és értékes kultúrájáról, népviseletéről, népszokásairól, amelyekkel már régóta alakítják és színesítik Olaszország néprajzi térképét, azt is el kell ismernünk, hogy azok - kizárólag politológiai szempontból vizsgálva - nem váltak jelentős érdekcsoportokká.

A jelen tanulmány elsősorban nem egy előre lefektetett tézis bizonyítása érdekében jött létre, a bemutatandó regionális minták alapján sokkal inkább fel szeretné kérni az olvasót a leírtak továbbgondolására és egy saját, egyéni tanulság levonására. Ehhez az írás két alapvető támpontot kíván nyújtani. Egyrészt bemutatja napjaink Olaszországa politikai súllyal bíró regionális nemzeti kisebbségeinek a vázlatos történetét és azokat a sajátos szociális, nyelvi és kulturális körülményeket, amelyek közrejátszottak abban, hogy az adott nemzeti kisebbségek, valamint az őket képviselő pártok napjainkra meghatározó eróvé váljanak. Ehhez kapcsolódva megvizsgálja az egyes nemzetiségi pártok történetét, politikai irányvonalát, illetve szövetségi rendszerét is. Másrészt felvázolja a mai Olaszország területén élő őshonos kisebbségek autonómiájához vezető folyamatot, hogy általa támpontokat és mintákat nyújtson napjaink hasonló helyzetben élő európai kisebbségeinek a sorsuk békés módon történő rendezéséhez és jobbításához. Mindebből fakadóan a tanulmányvégi összegzés sem egy ex cathedra konklúziót szeretne kínálni, inkább a bemutatott minták holisztikus értékeléséhez felhasználható szempontrendszert.

\section{Általános jogi keretek}

Általánosságban megfigyelhető, hogy - Európában legalábbis - az etnikai alapú politizálás kezdete mindig egy demokratizálódási folyamathoz kötődött. Miként Vizi Balázs (2007) is utalt rá, az etnikai jellegú politizálás mindig is összefüggött egy elnyomó 
rezsim elmúltával. Ez Közép- és Kelet-Európában a szovjet birodalom összeomlását jelentette. Az olaszországi nemzeti kisebbségek némiképp szerencsésebbnek mondhatják magukat, hiszen lényegében a nemzetiszocialista és fasiszta rezsimek összeomlását követően, azaz már a 20. század közepétől elkezdhették bontogatni szárnyaikat. A folyamat végül elvezetett oda, hogy a nyolcvanas évekre Nyugat-Európában az etnikai alapú politizálás már a virágkorát élte, aminek a legszembetúnőbb jelei a regionális politikai pártok egyre nagyobb számú választási sikerei voltak. Olaszországban a nemzeti regionális politizálás egyik szép mérföldkövének 1999. december 15-ét tekinthetjük, amikor is az Olasz Köztársaság Parlamentje elfogadta a történelmi nyelvi kisebbségek védelméról szóló CDLXXXII. törvényt, amelynek 2. §-a értelmében az ország területén élő albán, katalán, germán, görög, szlovén, horvát, francia, provanszál, friuli, ladin, okszitán/okcitán, valamint szárd nyelvek az állam különleges védelmét élvező státusszal bírnak (vö. 1. ábra). Mindenképp szükséges kiemelni, hogy e törvényi rendelkezés csak az őshonosnak számító történelmi nyelvi kisebbségeket óvja, és természetesen nem jelenti azt, hogy Olaszországon belül ne léteznének más - például afrikai, dél-amerikai vagy ázsiai -, akár nagyobb lélekszámú, a saját anyanyelvüket beszélő etnikumok is. Ez utóbbiak esetében azonban a 20.-21. századi bevándorlás egyik velejárójáról, s nem a hosszú generációk óta az olasz csizma területén élő történelmi gyökerú népcsoportokról beszélhetünk.

A regionális politika másik fontos alappillére nem kisebb jogszabály, mint maga az Olasz Köztársaság Alkotmánya, amelynek 116. §-a biztosítja Friuli-Venezia Giulia, Trentino-Alto Adige, Valle d'Aosta (magyarul gyakorta: Aosta-völgy), illetve Szardínia és Szicília speciális autonóm státuszát. Az első három esetében az alkotmány biztosította autonómia a helyi nyelvi kisebbségek védelme miatt bír jelentőséggel, míg az utóbbi kettőében a rendelkezés inkább gazdasági okokra vezethető vissza, s az adott térség felzárkóztatása érdekében fontos. 


\section{Külügyi Szemle}

1. ábra

A történelmi nyelvi kisebbségek védelméről szóló 1999. évi CDLXXXII. törvény által nevesített nyelvek és azok területi elhelyezkedése Olaszország térképén

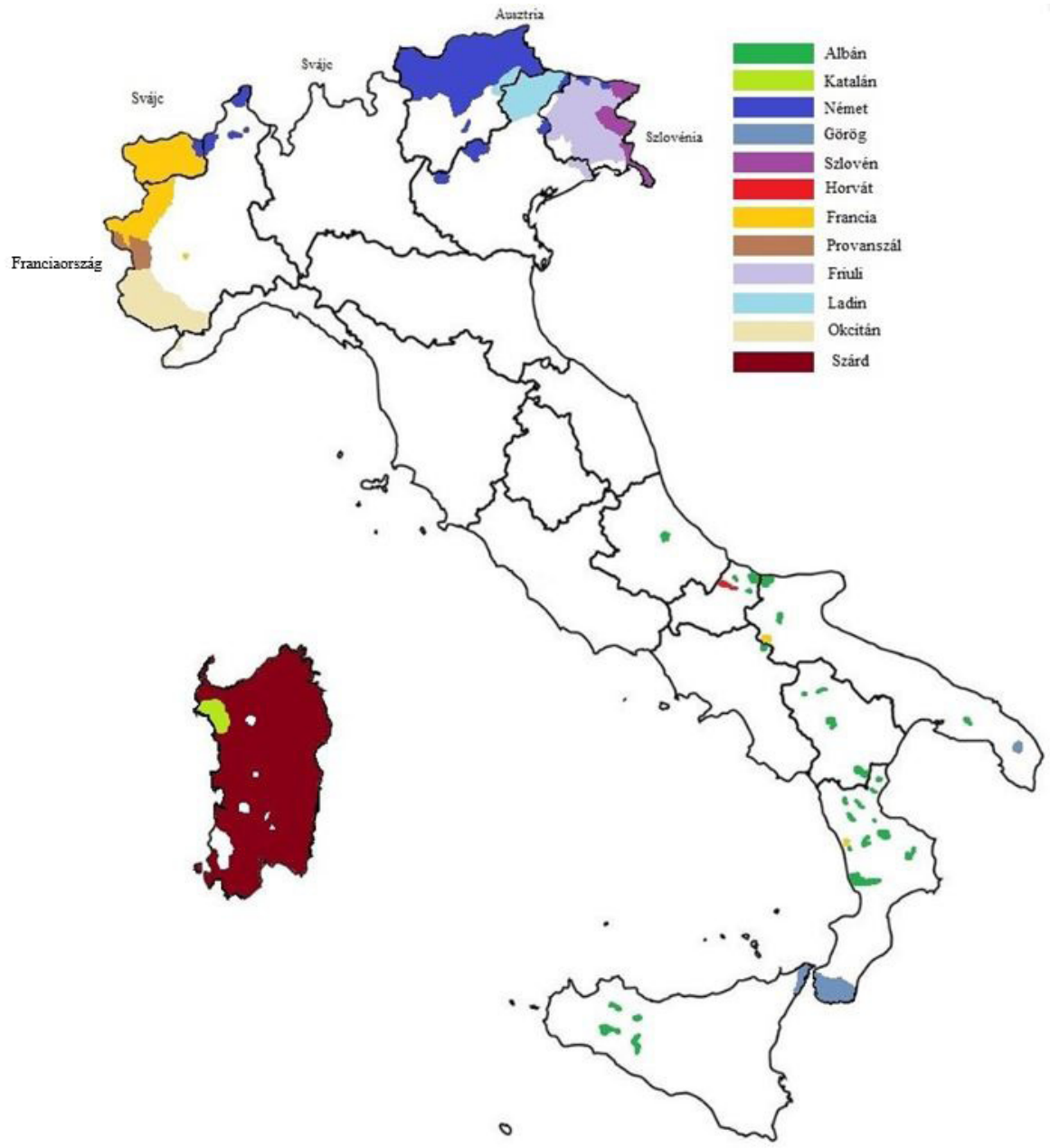

Az elemzés megkezdése előtt érdemes kiemelni, hogy az érintett pártokat - a kisebbségi létükből és a nyilvánvaló közös sorsukból fakadóan - nem elhanyagolható mértékú együttmúködés köti össze. Ezeket az együttmúködéseket és egyéb választási szövetségeket a következő oldalon található értelmező ábra szemlélteti (1. táblázat). 
1. táblázat

Szakmai és választási együttmúködés az egyes nemzeti kisebbségi pártok között

\begin{tabular}{|c|c|c|c|c|}
\hline & $\begin{array}{c}\text { Südtiroler } \\
\text { Volkspartei }\end{array}$ & $\begin{array}{c}\text { Union } \\
\text { Valdôtaine }\end{array}$ & $\begin{array}{c}\text { Partito Sardo } \\
\text { d'Azione }\end{array}$ & $\begin{array}{l}\text { Slovenska } \\
\text { Skupnost }\end{array}$ \\
\hline $\begin{array}{c}\text { Südtiroler } \\
\text { Volkspartei }\end{array}$ & & & & \\
\hline $\begin{array}{c}\text { Union } \\
\text { Valdôtaine }\end{array}$ & 1 & & & \\
\hline $\begin{array}{c}\text { Partito Sardo } \\
\text { d'Azione }\end{array}$ & 2 & 4 & & \\
\hline $\begin{array}{l}\text { Slovenska } \\
\text { Skupnost }\end{array}$ & 3 & 5 & 6 & \\
\hline 1 & \multicolumn{4}{|c|}{ Szakmai együttmüködés 2012-töl } \\
\hline 2 & \multicolumn{4}{|c|}{ 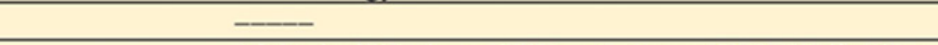 } \\
\hline 3 & \multicolumn{4}{|c|}{1 képviselöi hely az SKK számára az SVP EP-listáján } \\
\hline 4 & \multicolumn{4}{|c|}{1984 (ЕР), 1989 (ЕР) } \\
\hline 5 & \multicolumn{4}{|c|}{1999 (Törvényhozás) } \\
\hline 6 & \multicolumn{4}{|c|}{1999 (Törvényhozás) } \\
\hline
\end{tabular}

\section{A németajkú regionális pártok}

Az első világháború során az antanthatalmak - több más területtel együtt - a történelmi értelemben vett egységes Tirol déli területeit az Olasz Királyságnak ígérték a katonai támogatásért cserébe. A háború lezárultát követően, a Saint-Germain-en-Layekastélyban 1919-ben aláírt békeszerződés értelmében a darabjaira hullt Osztrák-Magyar Monarchia dél-tiroli része - az előzetes ígéretekhez híven - valóban olasz fennhatóság alá került, míg Nyugat- és Kelet-Tirol az első Osztrák Köztársaság szövetségi tartományává vált. A második világháborút követő 1946-os párizsi tárgyalások során megerősítették az 1919-es határokra vonatkozó döntést, és Dél-Tirol Olaszország területe maradt. Napjainkban közigazgatásilag teljes Dél-Tirol Trentino-Alto Adige tartomány részét képezi. A tartomány két autonóm megyére, az olaszajkú Trentóra (Provincia Autonoma di Trento) és a németajkú Bolzanóra (Provincia Autonoma di Bolzano/ Autonome Provinz Bozen) oszlik, Trento, illetve Bolzano/Bozen megyeszékhelyekkel, amelyek közül Trento egyben a teljes tartomány székhelye is.

A terület jelenlegi politikai berendezkedésének a vizsgálatához vissza kell nyúlnunk Benito Mussolini fasiszta diktatúrájáig, amely a dél-tiroli osztrák identitás - ideértve a politikai és a kulturális mozgalmakat is - teljes eltörlését tűzte ki céljául. Ezt többek között az olaszajkú lakosságnak a - főként Bolzanóba történt - szervezett betelepítésén keresztül akarta elérni. A németajkú és a ladin lakosság érdekeit és kultúráját képviselő pártok és szervezetek csak a második világháború végét követően kezdhették meg ismét a múködésüket. A Dél-tiroli Néppártot (Südtiroler Volkspartei/Partito Popolare Sudtirolese, SVP) 1945. május 8-án alapították meg, a bolzanói kereskedő, Erich 
Ammon vezetésével: Ammon a fasizmussal szembeni ellenállás kötelékeiben harcolt több társával együtt hívta életre az új regionális szervezetet, amelynek szimbóluma a havasi gyopár lett. Az emblémája miatt a pártot ezért igen gyakran allegorikusan csak mint das Edelweiss [Havasi Gyopár] említik. A helyi népszerűségét és beágyazottságát jól szemlélteti, hogy a párt taglétszáma már 1945 szeptemberében ötvenezer fő volt (Holzer és Schwelger, 1998).

Amennyiben alaposabban szemügyre vesszük a pártot, azt láthatjuk, hogy annak kezdeti fejlódése tökéletesen megegyezik az országos nagypártokéval: a történelmi, ideológiai, filozófiai elődök jelentette gyökerekből táplálkozva, majd a fasizmus elleni harcok során szerzett morális presztízs által megerősödve, a demokrácia és a függetlenség kivívását követően jogi keretek közé szervezte az addigi illegális múködését. E jelenség volt megfigyelhetô a háború utáni valamennyi jelentősebb - úgy a kereszténydemokrata, mint a kommunista vagy éppen szocialista, republikánus és liberális - párt esetében is, amelyek a gyökereiket a Nemzeti Felszabadítási Bizottság (Comitato di Liberazione Nazionale, CLN) ernyője alatt vívott harcokból eredeztették.

Az SVP az Andreas-Hofer-Bund nevú dél-tiroli antifasiszta ellenállási mozgalomból fejlődött ki, azonban a köztársaság kivívását követően sem érezhette úgy, hogy elérte volna a remélt függetlenséget, hiszen Dél-Tirol nem az anyaország, Ausztria, hanem Olaszország fennhatósága alatt maradt. Az 1946. szeptember 5-én Karl Gruber osztrák és Alcide De Gasperi olasz külügyminiszter által aláirt kétoldalú egyezmény Dél-Tirol számára területi autonómiát, Ausztria részére pedig védhatalmi jogokat biztosított (Berényi, 2016). Az olasz alkotmányozó nemzetgyűlés 1948-ban megerősítette az egyezményt, ám azt a helyi lakosság egy jelentős része nem találta elégségesnek. A következő években erőteljes, de békés természetű tiltakozási hullám indult el az Edelweiss szervezésében a területi autonómia kiszélesítése érdekében, amely 1957-ben, a Castel Firmiano/Schloss Sigmundskron településen a párt akkori elnöke, Silvius Magnago vezetésével lezajlott, mintegy 35.000 fős tüntetéssel érte el a csúcspontját (Holzer és Schwelger, 1998).

Mint az ebből is látható, az SVP deklaráltan békés és demokratikus eszközökkel küzdött a terület autonómiájáért. Léteztek azonban - kezdetben szervezetlen, majd az idő előrehaladtával egyre szervezettebbé váló - csoportok, amelyek mindezt radikálisabb eszközökkel kívánták elérni. Közéjük tartozott a Georg Klotz vezette Befreiungsauschuss Südtirol elnevezésú „terrorista" csoport, amely többnyire dinamittal elkövetett robbantásokkal hívta fel magára a figyelmet. Leopold Steurer történész álláspontja szerint a dél-tiroli radikálisok közel sem jelentették a lakosság reprezentatív hányadát. Azok sokkal inkább a már letúnt hitleri Németországhoz kötődő csoportot alkottak, amelynek tagjai korábban a Wermacht kötelékében harcoltak és szereztek kitüntetéseket, később pedig - a leggyakrabban a hajdani Osztrák-Magyar Monarchia tiroli területein múködő közrendvédelmi Tiroler Schützen mintájára létrejött - folklorisztikus és hagyományőrző 
Schützen egyesületek keretein belül lelt új követőkre (L'Adige, 1961. 1. o.). Georg Klotz hat gyereke közül egyedül Eva lépett politikai pályára, és 2007-ben életre hívta a Süd-Tiroler Freiheit - Freies Bündnis für Tirol nevű, szélsőségesen szeparatista pártot, amely napjainkban is a „Rómához lojális"-Dél-tiroli Néppárt ellenében politizál.

A földrajzi terület autonómiatörekvéseinek következő lépcsőfoka az volt, amikor 1960-ban Ausztria - az SVP kezdeményezésére - az ENSZ New York-i közgyűlése elé terjesztette Dél-Tirolnak az Olaszország által nem kellő mértékben biztosított autonómiájával kapcsolatos ügyet. A világszervezet helyt adott Ausztria indítványának, és arra kötelezte a két államot, hogy a helyzet rendezése érdekében kezdjék meg a tárgyalásokat. Hosszas, kezdetben Ausztria és Olaszország, később az SVP és az olasz kormány között zajlott egyeztetések eredményeként kidolgoztak egy intézkedéscsomagot, s azt végül 1969-ben a dél-tiroli megyei közgyúlés is elfogadta. A döntés értelmében folytatódhatott az a törvényalkotási eljárás, amely az 1972. január 20-án hatályba lépett, immáron második autonómiatörvény megalkotásához vezetett. A szakértők ezt a pillanatot tekintik Dél-Tirol felvirágzása kezdetének. 1992-ben mindkét fél végrehajtottnak nyilvánította az 1969-es intézkedéscsomagot, s erről tájékoztatták az ENSZ akkori főtitkárát, Boutros Boutros-Ghalit is. A terület etnikumainak békés együttélését mi sem bizonyítja jobban, mint az 1995. május 19-én Rómában nagy sikerrel lezajlott olaszosztrák csúcstalálkozó, amelyen Wolfgang Schüssel akkori osztrák külügyminiszter és alkancellár kijelentette, hogy „egy olyan időszakban, amelyben Európa egyéb régióiban a kisebbségek ellen irányuló intolerancia, idegengyűlölet és egyéb véres események ütik fel a fejüket, a két érintett ország bölcsen belátta, hogy egy gonosz cselekedetből csakis további gonoszságok eredhetnek, ezért inkább a kölcsönös megegyezés irányába tekintett" (Luverà, 1996).

A dél-tiroli területi autonómia biztosítására létrejött bilaterális rendelkezések egyik figyelemre méltó eleme Trentino-Alto Adige tartomány vezetési és döntéshozatali mechanizmusa, amely az egyes népcsoportok közti tökéletes szimmetrián nyugszik. A területi autonómia érvényesítése, valamint a németajkú lakosság azonos jogainak biztosítása érdekében egy-egy ciklus első felében az egész tartomány elnöke az, aki Trento autonóm megye elnöke (Trento székhellyel), míg a ciklus második felében Bolzano autonóm megye elnöke (Bolzano székhellyel) (Berényi, 2016, 59. o.). A tartományi közgyúlés tagjait szintén a területi és kisebbségi autonómiák figyelembevételével választják meg: a két megye lakossága külön-külön megszavazza a saját közgyúlésük (a Consiglio della Provincia Autonoma di Trento, illetve a Südtiroler Landtag) 35 tagját, akik ezt követően az így 70 fős tartományi közgyűlés (Consiglio Regionale del Trentino-Alto Adige/ Regionalrat) tagjaivá válnak. Fontos kiemelni, hogy - megelőzendő az etnikai választói csoportok arányának a külső beavatkozás révén történő megbontását - a megyei szintú választások során csak azok az állampolgárok bírnak aktív választójoggal, akik a választások kiírását megelőző négy évben a tartományban állandó, bejelentett lakcímmel rendelkeztek (Dabis, 2015). 


\section{Külügyi Szemle}

Dél-Tirol esetében gyakorta csak a németajkú lakosokra gondolunk, és hajlamosak vagyunk megfeledkezni a ladin népességről, amely viszont szintén fontos - igaz, csekély létszámú - csoportja a tartomány teljes lakosságának. A tartományi rendelkezések azonban nem hagyják figyelmen kívül őket sem, mivel - eltekintve az arányosság elvétôl - kötelezően előírják a ladin népcsoportnak a megyei vezetésben történő képviseletét. Ugyanez a jogszabály előírja a nők kötelező és arányos képviseletét is (Dabis, 2015, 36. o.).

Az SVP a megalakulásától kezdve, mondhatni töretlenül, az országot közel fél évszázadon át kormányzó Keresztény Demokráciát (Democrazia Cristiana, DC) tekintette az elsődleges szövetségesének. A DC 1992-es összeroppanását, majd széthullását követően az SVP a DC romjain létrejött Olasz Néppárttal (Partito Popolare Italiano, PPI) lépett választási koalícióra. A PPI balközépre történt későbbi betagozódása az SVP szövetségi politikáját is jelentősen befolyásolta, míg végül a 2000-es évekre a balközép Demokrata Párt (Partito Democratico, Pd) stabil szövetségese lett. Az SVP-nek a jobbközépről balközép irányú elmozdulása természetesen erős ellenérzést váltott ki az addigi ernyőszervezet jobbszélén, amely platformok fokozatosan leváltak róla. E csoportok egyfajta belső ellenzékként mindig is léteztek, azonban az 1992 előtti, sziklaszilárdnak tetsző politikai rendszerben nem túnt szerencsésnek elkezdeni egy komolyabb kiválási folyamatot. Az Olaszország korábbi kétpólusú pártstruktúráját (kereszténydemokratakommunista dialektika) 1992 és 1994 között megbontó politikai válság és az azt követő pártalakítási hullám ugyanakkor számukra is követendő példát kínált, és Dél-Tirolban gombamód szaporodtak el az új helyi nemzetiségi pártok.

Érdemes megemlíteni közülük a legelsőként alakult, ám napjainkra politikailag már jelentéktelenné vált jobbközép BürgerUnion für Südtirolt. E párt a belső feszültségei következtében tovább szakadt, és kivált belőle a korábban már említett Süd-Tiroler Freiheit. Ez utóbbi képviseli a legradikálisabban Dél-Tirol elszakadásának ügyét, nyíltan felvállalva a véleményüket, amely szerint Dél-Tirol nem Olaszország része. Hasonlóképpen szót érdemel a Die Freiheitlichen, amely az előbbitől mérsékeltebb irányban helyezkedik el a térség politikai palettáján. A főbb európai irányvonalaknak megfelelően nem sokat váratott magára egy dél-tiroli zöld párt, a Verdi-Grüne-Vërc megalakulása sem (Dabis, 2015, 40. o.). A párt hivatalos nevében érdemes megfigyelni az olasz, német és ladin megnevezés egyidejú használatát, ugyanis ez az egyetlen szervezet, amely figyelmet fordított mindhárom népcsoport megjelenítésére. A 2008-as világgazdasági válság, amely globálisan megnövelte a protesztpártok - így Olaszországban az 5 Csillag Mozgalom (Movimento 5 Stelle, M5S) - támogatottságát, természetesen Dél-Tirolban is nyomot hagyott a politika lakmuszpapírján. A megyében az M5S Paul Köllensperger informatikai nagyvállalkozón keresztül képviseltette magát, de amikor nézeteltérésbe került a pártvezetéssel, kivált a szervezetből, és saját pártot alapított Team Köllensperger (Team K) néven, amely azonban ideológiájában nem távolodott el az egykori anyapárt közvetlen demokráciát és rendszerkritikusságot hirdető elveitől. 
Az évtizedek múlásával a megalakult pártok közül minden kétséget kizáróan a Freiheitlichen lett az, amely a legnagyobb százalékot tudta kiszakítani az SVP szavazótáborából, azonban mindez nem jelenti azt, hogy az SVP vezető szerepe veszélybe került volna Bolzano megyében. Napjainkban a dél-tiroli politikai tájkép úgy fest, hogy míg az SVP kiszámíthatóságot, a fennálló jogi keretek által biztosított autonómiát és stabilitást kínál a választók számára, addig mind a Freiheitlichen, mind a Süd-Tiroler Freiheit a szecesszionista gondolat hangsúlyozásával igyekszik - olykor egymással versengve - újabb szavazókat bevonzani. A Verdi-Grüne-Vërc pedig egy némiképp közbenső megoldást javasol, mivel kritizálja ugyan az SVP által kivívott autonómiát és annak mértékét, mégis egy újratárgyalandó - sorrendben immáron a harmadik - autonómiaszerződés keretei között, de továbbra is Olaszország határain belül képzeli el Dél-Tirol jövőjét (Dabis, 2015, 48-49. o.).

A 21. századra az SVP elsődleges belpolitikai célja az Olaszországban élő németajkú és ladin népesség nemzeti identitásának, önrendelkezési jogának, nyelvének és kultúrájának a megvédése lett, valamint e népcsoportok minél erősebb kapcsolattartása azzal a közép-európai kulturális térrel, amelyhez - szemben a Mediterráneumot megjelenítő Olaszországgal - mindig is sorolta Dél-Tirolt. Külpolitikájában a párt az egységes és föderális Európa nyelvi kisebbségeinek a minél nagyobb arányú védelme, valamint minél tágabb autonómiájának a segítése és kivívása mellett tesz hitet. Oktatási téren fontosnak tartja az anyanyelvi oktatás elősegítését, továbbá két idegen nyelv elsajátíttatását a köznevelési intézményekben.

Amikor az SVP alapvető politikai programpontjait vesszük szemügyre, nem szabad megfeledkezni a párt regionális voltáról, valamint az adott régió természeti értékeiről és kincseiről sem, amelyek közül elsősorban az Alpokat, a hegyi folyókat és patakokat, illetve a hozzájuk kötődő mezőgazdaságot, továbbá az alpesi turizmust kell kiemelni. Épp ezért a párt a környezetvédelem szükségességét, a megújuló energiaforrásokra épülő infrastruktúra növekedésének a támogatását, valamint - a szabadpiaci verseny fontosságának hangsúlyozása mellett - a mezőgazdasági termelés korszerūsítését szorgalmazza.

Az Edelweiss szociális téren a társadalom alapegységének a családot tekinti, amelynek védelmére kiemelt figyelmet fordít, és fontosnak tartja, hogy a nőket a férfiakkal egyenrangú félként ismerjék el, ezért a programjában külön kitér a háztartásbeli aszszonyok szerepére, akik - álláspontjuk szerint - a dolgozó nőkkel azonos társadalmi státuszt érdemelnek (Holzer és Schwelger, 1998).

Természetesen alapvető fontosságú kérdés, hogy a célkitűzéseit az SVP kivel vagy mely pártszövetség keretein belül tudja és kívánja érvényre juttatni. Dél-Tirol olaszajkú népessége javarészt a megyeszékhelyen, Bolzanóban koncentrálódik, és ott alkot többségi társadalmat (ők teszik ki a város lakosságának mintegy 75 százalékát). Ez a demográfiai adat erősen befolyásolja az olasz országos nagypártok helyi 
választási stratégiáját is. Azok ugyanis a megyei szintú választások alkalmával - ahol tehát többségben vannak a németajkú szavazók - általában valamelyik nemzetiségi párttal hoznak létre szövetséget, míg Bolzanóban saját, olasz jelölteket állítanak, akik győzelmüket követően a nemzetiségi pártokkal koalícióban kormányozzák a várost. Nem volt ez másképp a 2020. október 4-én lezajlott bolzanói helyhatósági választáson sem, ahol ezúttal is az olaszajkú jelöltek kerültek be a második fordulóba, míg végül - nagyrészt az SVP támogatásának köszönhetően - a balközép Renzo Caramaschi nyerte el a polgármesteri széket. A 2018-as törvényhozási választások során és az azokat követő egyes tartományi vagy megyei megmérettetéseken, akárcsak az ország legtöbb tartományában, Dél-Tirolban is egyértelmúen előretört a Matteo Salvini által vezetett jobb-jobbközép Liga (Governo italiano. Ministero dell'Interno, 2018), amellyel az SVP - hosszas és agresszív vitákat követően - végül koalíciókötésre kényszerült. Tehát a legutóbbi évek országos szintú politikai változásai úgy hozták, hogy bár ideológiájában és retorikájában az SVP továbbra is inkább a balközép térfélen helyezkedik el, helyi szinten az országos tendenciákhoz igazodott.

\section{A frankofón regionalizmus}

Mint a bevezetôben már utaltam rá, bár a németajkú sorstársánál kisebb létszámú, ám szintén fontos politikai befolyással bír Olaszországon belül az Aosta-völgyben a frankofón nemzeti kisebbség és a hozzá köthető politikai képviselet. Habár a két etnikum jelene erős hasonlóságokat mutat, a frankofón lakosság sorsa mégis másképp alakult: bizonyos szempontból talán könnyebben és békésebben, mint a németajkú nemzetiségé.

Történelmileg az Aosta-völgynek mind a francia-, mind az olaszajkú lakossága - a svájci kantonális mintát követve - inkább erős helyi, mintsem nemzeti (francia vagy olasz) identitással rendelkezett (Vizi, 2011). Így nem csoda, hogy az évszázadok során jelentős ellenállást mutatott mindennemú (akár Olaszország, akár Franciaország irányából érkező) centralizációs törekvéssel szemben. Az ott élők mindig is arra törekedtek, hogy azok maradjanak, akik voltak: nem kívántak se franciává, se olasszá válni, hanem meg kívánták őrizni az Aosta-völgyi identitásukat. Ez jelenti a kulcsot a földrajzi terület és lakossága modernkori történelmének és fejlődésének a megértéséhez.

A centralizációs törekvés már a 19. században megjelent a frissen egyesült Olaszország olasz-francia vegyes kultúrájú vezetése részéről is, azonban a csúcspontját minden bizonnyal a Mussolini-rezsim erőszakos nyelvi asszimilációs politikája idején érte el, így nem meglepő, ha az Aosta-völgy lakossága a rezsim térvesztését, majd bukását követóen szinte azonnal követelni kezdte a decentralizációt. Erről a Nemzeti Felszabadítási Bizottság igyekezett is folyamatosan biztosítani a területen élő közösséget, és Mussolini bukása után az intézkedések sem várattak sokat magukra. 
Az aostai ellenállás először az 1943-ban elfogadott chivassói nyilatkozatban adott hangot az autonómiára vonatkozó igényének, majd a fasizmus összeomlása nyomán felállt új olasz vezetés igencsak hamar, a tartomány autonóm státuszáról rendelkező 1945. évi DXLV. (IX. 7.) királyi helytartói rendeletben ismerte el a terület jogállását. A szabályozást Savoyai Umberto piemonti herceg, királyi helytartó alkotta meg, majd a Ferruccio Parri vezette olasz kormány fogadta el 1945. október 8-án. A helytartói rendelet tartalmát a frissen létrejött Olasz Köztársaság Alkotmányozó Nemzetgyűlése is jóváhagyta, és áldását adta a tartomány autonóm státuszára, amely végül 1946. február 26-tól lépett érvénybe. A terület autonómiáját az 1948. január 1-jén hatályba lépett alkotmány is megerősítette. A sürgős jóváhagyás okkal történt. Mint fentebb utaltam rá, az Aostavölgy mindig is inkább erős helyi, mintsem francia vagy olasz identitással rendelkezett, ezért nem is annyira a Franciaországhoz vagy Olaszországhoz való tartozás jelentette az ottaniak számára a lényegi kérdést, mint inkább az autonómia elérése. Ezzel állt teljes átfedésben a háború utáni Olaszország vezetésének az érdeke; ők ugyanis határozottan féltették az ország területi integritását, és aggódtak a többségében frankofón népességú tartomány Franciaországhoz való esetleges közeledése miatt. Az autonómia megadásával a köztársaság egyben azt is biztosítani próbálta, hogy az Aosta-völgy ne kívánjon elszakadni.

Ez volt tehát az a történelmi és társadalmi kontextus, amelyben az olaszországi frankofón lakosság létrehozta a saját érdekérvényesítő erejét is: az Aosta-völgyi Uniót (Union Valdôtaine/Unione Valdostana, UV). ${ }^{2}$ A párt a tartomány autonóm státuszát elismerő rendelet meghozatalát követő alig néhány napon belül, 1945. szeptember 13-án alakult meg.

Az UV politikai irányvonala, amely mindig is nagymértékben összefüggött az Aostavölgyi identitással, három alapvető pilléren nyugszik: a frankofón identitás megőrzése az olasz állam keretei között; kötődés az Alpokhoz és a hegyvidéki életformához; az elért autonómia megőrzése és további erôsítése (Cuaz, 1996, 183. o.). A párt mindig is igyekezett alkalmazkodni a helyi társadalom önrendelkezési igényeihez. A világszemléletét ugyancsak erőteljesen alakította a még a Nemzeti Felszabadítási Bizottság kötelékében, az Alpok vonulatai között vívott harcok alatt kialakult erős antifasiszta érzület. A CLN meghatározó jelenlétét - mind a tartományi, mind a pártvezetésben - mi sem szimbolizálja jobban, mint hogy a tartomány első, 1946. január 10-i gyűlését annak felügyelete alatt rendezték meg.

Fontos kiemelni az UV egy másik, igen jelentős tápgyökerét is, amely nem más, mint a köztársasági államformához való nagyfokú ragaszkodás. Ahogyan a kulturális és nyelvi értelemben vett anyaország, Franciaország rendkívül büszke a saját köztársasági

2 Az Union Valdôtaine-nel összefüggő információk közléséhez alapvető segítségemre volt a párt hivatalos honlapjának a szervezet történelmét feldolgozó aloldala (Union Valdôtaine, 2005). 


\section{Külügyi Szemle}

államformájára, úgy az Aosta-völgy is mindig erős köztársaságpárti érzelmeket táplált. Ezt bizonyítja, hogy a lakosság az 1946. június 2-i alkotmányos népszavazáson az országos átlagot meghaladó $(63,5: 36,5)$ arányban a köztársasági államforma mellett foglalt állást, nem utolsósorban az UV javaslatára.

Amennyiben a párt szövetségi rendszerét tesszük a vizsgálódásunk tárgyává, azt mondhatjuk, hogy - célorientáltságából fakadóan - soha nem tartotta fontosnak a politikai partner színezetét, inkább az volt fontos számára, hogy melyik partnerrel és miként érhetô el egy meghatározott cél és a nagyobb mértékú önrendelkezés. A második világháborút követő választások közül az UV szinte valamennyiben a tartomány viszonylagos többséggel bíró politikai szervezete volt, azonban könnyen belátható, hogy ez a helyzet koalíciókényszert váltott ki. A megalakulását követően - tekintettel a Keresztény Demokrácia felívelésére is - az UV elsősorban a DC szövetségét kereste, azonban az idő múlásával egyre inkább úgy ítélte meg, hogy az Aosta-völgyi kereszténydemokraták a leginkább a római központ által elvárt álláspontot, s nem a területnek az UV által meghatározott érdekeit képviselik, ezért egyre gyakrabban fordult a baloldalhoz támogatásért. Ez a fajta jobb-bal ingamozgás általánosságban határozta meg az UV történetét, és nemegyszer vezetett pártszakadáshoz, majd újbóli egyesüléshez. Megemlítendő a párt balszárnyának az 1972-es kiválása, Aosta-völgyi Progresszív Unió (Union Valdôtaine Progressiste/Unione Valdostana Progressista, UVP) néven, amely a kereszténydemokraták soraiból helyi szinten ugyancsak kivált balszárnnyal, a Demokratikus Néppárttal (Democratici Popolari, DP) lépett szövetségre. A történelmi húség kedvéért kiemelendő, hogy 1976-ban az UV korábban szétvált platformjai ismét egyesültek.

Az UV koalíciós politikája szempontjából szintén hangsúlyozandó a viszonylag stabil együttmúködés egy másik - mint a bevezető gondolatok között már utaltam rá belső regionális formációval, a Szárd Akciópárttal, amellyel a hetvenes évektól meglévő választási szövetségükön keresztül mind 1984-ben (Governo italiano. Ministero dell'Interno, 1984), mind 1989-ben (Governo italiano. Ministero dell'Interno, 1989) sikerült egyenesen az Európai Parlamentbe juttatniuk egy képviselőt. Az Aosta-völgyi Unió és a Szárd Akciópárt esetében a történelmi-kulturális jellegből fakadó közelség és együttmúködés egy izgalmas megfigyelési szempontot kínál, ugyanis az egykori Savoyai Hercegség hozzávetőleg Savoie és Alpes-Maritimes megye (ma Franciaország), továbbá Piemont, Liguria, Aosta-völgy és Szardínia tartomány (ma Olaszország) területén helyezkedett el. A jelenlegi két területnek, illetve azok domináns pártjainak az 1980-as évektől kialakult szövetsége mindenképpen egy történelmi, kulturális és politológiai érdekességnek tekinthető. Az Aosta-völgyi Unió szövetségi politikája szempontjából nem elhanyagolható a Dél-tiroli Néppárttal 2012-ben kötött szakmai együttmúködése sem, amelynek célja, hogy a közös fellépés révén jobban ki tudják használni a két tartomány speciális státusza által kínált gazdasági és kulturális lehetőségeket, valamint erőteljesebben fel tudjanak lépni a közös érdekeik érvényesítéséért (Di Gennaro, 2012). 
Általánosságban kijelenthető, hogy az 1992-es és 1994-es törvényhozási választások során az egész politikai elitet elsöprő, földcsuszamlásszerú változás egyáltalán nem, vagy csak minimálisan érintette az Aosta-völgy közéletét. Helyi szinten mindkét esetben az UV, illetve a koalíciós partnerei könyvelhettek el nagyobb sikereket az ott amúgy sem számottevő tradicionális olasz pártok kárára. A komolyabb változás a 2008-as gazdasági válsággal érkezett el, amely - mint arról már Dél-Tirol esetén is szó volt - elősegítette a rendszerellenesnek tekintett pártok lokális előretörését. Annak ellenére, hogy az 5 Csillag Mozgalom az Aosta-völgyi választókörzetben jelentős sikereket könyvelhetett el, a tartományi vezetést nem befolyásolta lényegesen. Ugyanez jelenthető ki a 2018-as választásokat követő időszakról is, amely során a Liga az Aostavölgyben is előretört ugyan, de az UV helyi jelentőségét érdemben nem csökkentette. A 2020. szeptember 20-án és 21-én lezajlott tartományi választások is ezt a tendenciát erősítették meg. A megmérettetésen a jobbközép Liga relatív többséget szerzett ugyan a tartományi közgyúlésben, a frankofón pártok - az országos balközép pártokkal kiegészülve - mégis folytathatták a tartomány kormányzását.

Napjainkra az UV érdeklődési körének csak egy részét képezik az autonómiatörekvések, valamint az önállóság kiszélesítése érdekében vívott kisebb-nagyobb csaták. Az utóbbi egy-másfél évtizedben a párt igen helyesen felismerte, hogy kizárólag az erdőgazdálkodásra és a turizmusra nem lehet egy szilárd gazdaságot építeni, ezért a figyelme egyre inkább az alpesi környezetben végzendő mezőgazdasági és állattenyésztési tevékenység megkönnyítésére és támogatására kezdett irányulni (Cuaz, 1996, 197198. o.). Fontos még említést tenni a pártnak az autentikus környezet megóvására irányuló törekvéséről is. Az ENSZ által a hegyek nemzetközi évévé nyilvánított 2002 során az UV a témában felszólalt a világszervezet közgyúlése előtt, az április 20-án SaintVincent-ben tartott éves kongresszusát pedig az „Aosta-völgy és az Európai Unió - az alpesi lakosság esélyei a versenytársakkal szemben" témakörnek szentelte.

\section{A szlovén regionalizmus}

Országos viszonylatban a legkevésbé erős, ám helyi szinten mégis említésre méltó érdekképviselettel rendelkező nemzeti kisebbség az Olaszország legkeletibb területein - Friuli-Venezia Giulia tartomány Udine, Gorizia és Trieszt megyéjében, összesen harminckét településen - őshonos szlovén anyanyelvű kisebbség, amelynek lélekszámát napjainkban alig ötvenezer före becsülik. Ez a 60 milliós Olaszországban, de még az 1,2 milliós tartományban is csekélynek tekinthető. A szlovén nyelvet beszélők eredetileg a középkorban települtek a területre, és egyes megyékben - különösen Udinében - mind a mai napig őrzik a szlovén nyelv archaikus változatát, míg közvetítőnyelv gyanánt a mai irodalmi szlovént alkalmazzák (Kollár, 1999). 
A szlovén nemzeti kisebbség annyiban különbözik a németajkútól és a frankofóntól, hogy míg az utóbbiak a többségi társadalmat alkotják az adott autonóm megyében vagy tartományban, addig Friuli-Venezia Giulia demográfiai szempontból egy viszonylag hagyományos olasz tartománynak számít, túlnyomó többségében olaszajkú - azon belül a friuli dialektust beszélő - lakosokkal, akik között kisebbségben élnek a szlovén anyanyelvúek.

A kortárs Olaszország együttélése e kisszámú nemzeti kisebbségével - legalábbis a 20. század során - alapvetően békétlennek bizonyult. A tartományt alkotó népek, népcsoportok kohabitációjában keletkezett anomáliák jobb megértéséhez a térség helytörténetének vázlatos megismerése nyújthatja a kulcsot. A mai olasz-szlovén határvidék többnemzetiségú természetéból fakadóan már az Osztrák-Magyar Monarchia alatt is etnikai ellentétek színtere volt. Amikor a terület még a Monarchia része volt, elsősorban Trieszt képezte az olasz irredentizmus áhított tárgyát; az első világháborút követően viszont - amikor az érintett területet Olaszországhoz csatolták - a délszláv irredenta mozgalmak követelték maguknak. A háború során az egyes frontok, majd azt követően az országhatárok eltolódásával hol az egyik, hol a másik népcsoport érezhette magát győztes pozícióban, és az éppen vesztésre álló nemzetiség elnyomása és megalázása szinte egyetlen esetben sem váratott magára.

Az olasz fasizmus alatt Benito Mussolini hírhedten erőszakos olaszosítási politikája - ahogy arról már szó esett Dél-Tirol és az Aosta-völgy esetében is - nem kímélte meg a szláv lakosságot sem. A Mussolini-rezsim többek között elrendelte minden szintú szlovén és/vagy horvát oktatási intézmény bezárását, betiltotta a szláv újságokat, elrendelte és kizárólagossá tette az olasz nyelv használatát a közhivatalokban, a bíróságokon, továbbá a postai sürgönyökben. A rezsim az egyének életének olyan aspektusaiba is beleszólást engedett magának, mint a kegyeleti ügyintézés, ugyanis betiltotta a szlovén vagy horvát nyelvú sírfeliratokat. Összefoglalva: minden, ami minimálisan is emlékeztetett a szláv identitásra, államellenes cselekménynek minősült, így nem meglepő, hogy az Államvédelmi Különleges Törvényszék (Tribunale Speciale per la Difesa dello Stato, TSDS) több ízben is tartott kihelyezett ülést Triesztben. Arra vonatkozóan nem áll rendelkezésre pontos feljegyzés, hogy összesen hány szlovén vagy horvát nemzetiségú olasz állampolgárt ért valamilyen fokú sérelem a fasizmus alatt, azonban az bizonyos, hogy a TSDS összesen 131 - köztük 40 halálos - ítéletet hozott, együttesen 544 szlovén és horvát anyanyelvú személy ellen. 1927 és 1943 között egyetlen év sem telt el úgy, hogy ne szabott volna ki etnikai alapú itéletet általa államellenesnek tekintett „búncselekmények" miatt (Verginella, 2008, 18-22. o.).

Délszláv oldalról mindenképpen megemlítendők a jugoszláv (főként horvát, szlovén és szerb) partizánoknak az olasz lakossággal szembeni agressziói. Az olasz államnak a cassibilei fegyverszüneti egyezményt követő 1943-as összeomlásától kezdve az érintett területen jugoszláv partizáncsapatok olasz katonai és civil foglyokat ejtettek, majd 
különös kegyetlenséggel kivégezték őket. Mivel a környéket geológiai szempontból leginkább a karsztjelenségek határozzák meg, a legjellemzőbb kivégzési mód a foglyok több száz méter mély és rendkivül szúk (tányér/tölcsér alakú) karszttöbrökbe (olaszul: foiba, szlovénul: fojbah) való belelövése volt. A források nagy szórást mutatnak a tekintetben, hogy hány, a nép ellenségének kikiáltott és mindennemú megkülönböztetés nélkül, egységesen fasisztának bélyegzett olasz állampolgár lelhette halálát a töbrökben. Egyes források 3 és 5 ezer fő közé teszik a kivégzettek számát, míg mások több mint 10 ezer főt említenek (Oliva, 2015. 70-81. o.). Az olasz és a jugoszláv „ítélkezések" fascismo di confine [határ menti fasizmus] és massacro delle foibe [karszttöbrökbeli mészárlás] néven kerültek be az érintett államok kollektív tudatába.

Az országhatárok rendezésére - és bizonyos tekintetben a súlyosan megnyomorított lelkek megnyugtatására - az Olaszország és a szövetséges hatalmak között aláírt 1947-es párizsi békeszerződés 21. §-a tett kísérletet azáltal, hogy Triesztet és környékét - ideértve a mai szlovén tengerpartot is - szabad területként jelölte meg. A szerződés a teljes területet egy brit és amerikai fennhatóság alá vont „A” és egy jugoszláv ellenőrzésú „B" zónára osztotta fel. Az 1954-es londoni egyezmény az „A" zónát végérvényesen Olaszország részévé nyilvánította, míg a „B” jugoszláv fennhatóság alá került. A FriuliVenezia Giulia autonómiáját szabályozó statútumot - valamennyi jelenlegi autonóm tartomány közül utolsóként - az 1963. évi I. alkotmánymódosítással fogadták el.

A felsorolt szomorú történelmi események alapján bizonyos mértékig érthető, hogy az olasz állam és a szlovén kisebbség együttélését hosszú évtizedekig a kölcsönös hallgatás és elhallgatás, illetve szemlesütés határozta meg. Így aztán hiába alakult meg az autonómiatörvényt követően szinte azonnal, már 1963-ban a Szlovén Unió (Slovenska Skupnost/Unione Slovena, SSK) nevú nemzetiségi párt (Slovenska Skupnost, 2020), sokáig az országos nagypártok egyike sem lépett szoros kapcsolatba vele.

Az SSK föként abban különbözik az SVP-től és az UV-től, hogy míg azok mindig is az érintett területek többségi társadalmát képviselték, a szlovén nemzetiségi párt az autonóm tartományon belül egy tényleges kisebbségben élő etnikumot igyekezett képviselni. A párt már az 1963-as törvényhozási választások során önálló szlovén listát állított, ám nem jutott be a parlamentbe. Az 1992-es választások fordulópontot jelentettek az SSK életében, mert a Szárd Akciópárttal, az Aosta-völgyi Unióval, valamint a Dél-tiroli Néppártból éppen kivált BürgerUnion für Südtirollal együtt Föderalizmus (Federalismo) néven közös választási listát állított. A Föderalizmus egy képviselőt és egy szenátort tudott az olasz törvényhozás házaiba juttatni, azonban egyiküket sem az SSK delegálta (Governo italiano. Ministero dell'Interno, 1992). Az 1992-1994 közötti pártpolitikai válságot követően a szervezet - a dél-tiroli sorstársához hasonlóan - először a Keresztény Demokrácia romjain létrejött pártokkal, majd később (a pillanatnyi erőviszonyoknak megfelelően) a Demokrata Párttal ápolt szoros kapcsolatot. A magyar olvasók számára érdekes információ lehet, hogy a trieszti székhelyú, világhírú olasz kávéipari céget, 
az Illycaffè S.p.A.-t vezető - magyar származású - Illy család egyik kiemelkedő sarja, Riccardo Illy (Demokrata Párt) 2003-ban az SSK hathatós támogatásával lett FriuliVenezia Giulia elnöke, és kormányozta a tartományt egészen 2008-ig. A többi nemzetiségi párttal történő szövetség vonatkozásában fontos megemlíteni, hogy az európai parlamenti megmérettetések alkalmával az SSK egy jelöltje 1999 óta mindig helyet kap a Süd-Tiroler Volkspartei listáján, amely ily módon kíván hozzájárulni az olaszországi szlovén kisebbség európai szintú képviseletéhez.

Mint a fentiekból is kiderül, a 20. század utolsó évtizede óta az olasz határsáv politikai attitúdje is többnyire nyugalmat és viszonylagos harmóniát mutat, azonban a lelki megnyugvást követő "határrendészeti” békességre Szlovénia 2004-es európai uniós, sőt inkább a 2007-es schengeni csatlakozásáig várni kellett. 2007. december 20-án éjszaka olaszok és szlovének tömegei együtt ünnepelték a Gorizia (Olaszország) és Nova Gorica (Szlovénia) közötti fizikai határok lehullását, illetve - ahogy az Európai Bizottság akkori elnöke, José Manuel Durão Barroso fogalmazott - „az utolsó akadály elgördülését a béke, a szabadság és az európai egység elől" (Segatti és Guglielmi, 2008).

\section{Összegzés}

A tanulmányban megpróbáltam vázlatosan bemutatni az Olaszországban a legnagyobb politikai és társadalmi súllyal jelen lévő három nemzeti kisebbség - a németajkú, a frankofón és a szlovén népcsoport - esetenként rögös, máskor viszonylag könynyebb útját a jelenleg érvényben lévő autonómiáig. A leírás alapján egy alapvetően harmonikus kép bontakozik ki az olaszországi nyelvi kisebbségek és az olasz lakosság mai együttélésérôl. Talán felesleges megemlíteni, hogy ez az együttlét sem tökéletesen felhőtlen, bár valóban békésebb, mint a világ sok más országában. Felmerül tehát a kérdés, hogy ez a kedvezőbb helyzet vajon miból fakad. Erre számos választ adhatunk. Kiemelhetjük, hogy az olasz lakosság napjainkra kialakult befogadó attitúdje a történelem során tapasztalt elnyomatottságból ered; arra is emlékeztethetünk, hogy szerte a világban számos olasz állampolgár alkot ma is kisebbséget (elég csak az amerikai kontinens olasz kisebbségeire gondolnunk); szintén izgalmas megfigyelési szempontot kínál az a nézet, amely szerint az olasz társadalom felismerte a saját nyelve dialektális voltát (azaz a számos nyelvjárását), amely miatt az országban - eltekintve ezúttal a sztenderd olasztól - nem létezik egy többségi társadalom, mivel minden régió egyfajta nyelvi kisebbséget is alkot egyben.

Meglátásom szerint a fenti, többnyire szociális vagy nyelvészeti megközelítések mind figyelembe veendők egy elemzés során, azonban fontos lehet két egzaktabb - a biztonságpolitikai és a gazdasági - szempontot is beemelni jelen értelmezési keretek közé. Bár az olasz társadalom toleranciaszintje nem feltétlenül jobb más többségi társadalmakénál, a hivatalos olasz politikai vezetés párthovatartozástól függetlenül felismerte, 
hogy az autonómia biztosítása sokkal kevesebb belbiztonsági kockázatot hordoz, mint annak megtagadása. Ez utóbbi eklatáns példája a dél-tiroli intézkedéscsomag végrehajtása: míg az ottani terrorcselekményeknek 1956 és 1989 között több tucatnyian estek áldozatul, addig napjainkra - az autonómia biztosításával - az ott élő népcsoportok viszonylagos békében és megkérdőjelezhetetlen prosperitásban élnek. Az európai integráció láthatóan átértelmezte a határvidék fogalmát is. A határok lehullásával az egykori periferikus térségek a szomszédos országokkal történő kereskedelemnek és gazdasági kapcsolatoknak köszönhetően napjainkra központi szerepet kaptak, és különösen igaz ez, ha a szomszédos ország beszélt nyelve megegyezik a határsáv uralkodó nyelvével.

Gazdasági-kereskedelmi megközelítésből azt láthatjuk, hogy az Eurostat 2020 márciusában publikált adatai szerint Olaszországon belül az egy főre eső GDP összege Dél-Tirolban és az Aosta-völgyben a legmagasabb (az európai átlag 156, illetve 128 százaléka). Dél-Tirol ezzel európai összehasonlításban is a leggazdagabb húsz régió között foglal helyet (Eurostat, 2018). Ezek a kedvező adatok nagyrészt annak köszönhetőek, hogy Dél-Tirol és az Aosta-völgy virágzó kereskedelmi kapcsolatokat ápol a nyelvi-kulturális anyaországával, de a társadalmi és gazdasági fejlődésük szempontjából láthatóan nem mellékes, hogy az olasz állam milyen mértékben facilitálja az autonómiatörekvéseiket. A gazdasági fejlődés természetesen jelentős mértékben az Európai Unió égisze alatt létrehozott eurorégióknak is köszönhető. Ezek között megemlítendő a Tirol-DélTirol-Trentino eurorégió, az Aosta-völgy bevonásával megvalósult Espace Mont-Blanc eurorégió, illetve az Alpok-Adria Munkaközösség. Bár az ez utóbbi által lefedett terület még nem tartozik Európa legfejlettebb régiói közé, ám bizonyosan nagy szereppel bírt mind az olasz, mind a szlovén határ menti térség felzárkóztatásában.

Amikor az egyes európai országokban autonómiatörekvésekről esik szó, minden bizonnyal ezeket az olaszországi szempontokat és tapasztalatokat is érdemes figyelembe vennünk, hiszen az érintett felek múltban elkövetett hibáiból okulhatunk, a jelenük pedig értékes minta lehet mindannyiunk számára.

\section{Irodalomjegyzék}

Berényi Márk (2016). Az olasz alkotmányreform-folyamat főbb aspektusai, avagy búcsú a szimmetrikus bikameralizmustól. Külügyi Szemle, 15(1), 54-67.

Cuaz, Marco (1996). Alle radici di un'identità. Aosta: Le Château Edizioni.

Dabis Attila (2015). The South Tyrolean Party System. Minority Studies, (17), 33-52.

Di Gennaro, Edoardo (2012). Territori „speciali", un parro per il futuro delle autonomie. TrentoToday. A letöltés ideje: 2020. szeptember 1. http://www.trentotoday.it/cronaca/ rossi-svp-uv-difesa-autonomie-speciali.html.

Eurostat (2018). GDP per capita in EU regions. A letöltés ideje: 2020. szeptember 1. https://ec.europa.eu/eurostat/documents/2995521/10474907/1-05032020-AP-EN. pdf/81807e19-e4c8-2e53-c98a-933f5bf30f58. 


\section{Külügyi Szemle}

Gianni, Oliva (2015). Foibe. Le stragi negate degli italiai della Venezia Giulia e dell'Istria. Milánó: Mondadori.

Governo italiano. Ministero dell'Interno (1984). Archivio storico delle elezioni. A letöltés ideje: 2020. szeptember 1. https://elezionistorico.interno.gov.it/index.php?tpel=E\&dte $\underline{l=17 / 06 / 1984 \& \text { tpa }=Y \& \text { tpe }=A \& l e v 0=0 \& l e v s u t 0=0 \& e s 0=S \& m s=S \text {. }}$

Governo italiano. Ministero dell'Interno (1989). Archivio storico delle elezioni. A letöltés ideje: 2020. szeptember 1. https://elezionistorico.interno.gov.it/index.php?tpel=E\&dte

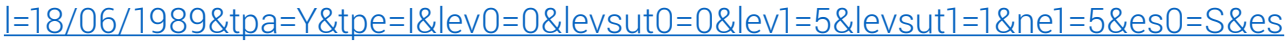
$1=S \& \mathrm{~ms}=\mathrm{S}$.

Governo italiano. Ministero dell'Interno (1992). Archivio storico delle elezioni. A letöltés ideje: 2020. szeptember 1. https://elezionistorico.interno.gov.it/index.php?tpel=C\&dt el $=05 / 04 / 1992 \&$ tpa $=1 \&$ tpe $=\mid \& l$ ev $0=0 \&$ levsut0 $=0 \& l e v 1=11 \&$ levsut $1=1 \&$ ne $1=17 \&$ es $0=S \&$ est $=S \& m s=S$.

Governo italiano. Ministero dell'Interno (2018). Archivio storico delle elezioni. A letöltés ideje: 2020. szeptember 1. https://elezionistorico.interno.gov.it/index.php?tpel=C\&dte $\mid=04 / 03 / 2018 \&$ tpa $=1 \&$ tpe $=A \& l e v 0=0 \& l e v s u t 0=0 \& e s 0=S \& m s=S$.

Holzer, Anton és Schwelger, Barbara (1998). The Südtiroler Volkspartei: A Hegemonic Ethnoregionalist Party. In Lieven De Winter és Huri Türsan (szerk.), Regionalist Parties in Western Europe (158-173. o.).

Kollár Anna (1999). Nyelvi kisebbségek Olaszországban. In Bakonyi Géza, Farkas Mária, Fogarasi Miklós (szerk.), Acta Romanica (217-230. o.).

L'Adige (1961). Trentaquattro cariche di dinamite fatte esplodere ieri in Alto Adige. (Június 12.).

Luverà, Bruno (1996). Oltre il confine. Bologna: Il Mulino.

Müller-Rommel, Ferdinand (1998). Theoretical Considerations and Framework of Analysis. In Lieven De Winter és Huri Türsan (szerk.), Regionalist Parties in Western Europe (17-27. 0.).

Sartori, Giovanni (1976). Parties and Party Systems: A Framework for Analysis. Cambridge: Cambridge University Press.

Segatti, Paolo és Guglielmi, Simona (2008). Stato, regione, Europa. In Paolo Segatti (szerk.), Lingua e identità in una regione plurale. II punto di vista di Friulani, Giuliani e Sloveni (93-115. o.).

Slovenska Skupnost (2020). Slovenska Skupnost. A letöltés ideje: 2020. szeptember 1. http://www.slovenskaskupnost.org.

Union Valdôtaine (2005). L'Union Valdôtaine, une présence longue de 60 ans. A letöltés ideje: 2020. szeptember 1. https://www.unionvaldotaine.org/datapage.asp?id=30\&l=1.

Verginella, Marta (2008). Il confine degli altri. La questione giuliana e la memoria slovena. Róma: Donzelli Editore.

Vizi Balázs (2007). Regionális, kisebbségi politikai mozgalmak és az európai integráció. In Szarka László, Vizi Balázs, Majtényi Balázs és Kántor Zoltán (szerk.), Nemzetfogalmak és etnopolitikai modellek Kelet-Közép-Európában (324-333. o.).

Vizi Balázs (2011). Valle d'Aosta tartomány és az alkotmányos reform. Kisebbségkutatás, 20(3), 361-377. o. 